\title{
QFD Analysis and Case Research for After-sales Service Quality of the
}

\section{Automobile 4S Store}

\author{
WEI Xing ${ }^{1, a, *}$, YANG Min $^{1, b}$
}

${ }^{1}$ Zijin College, Nanjing University of Science \& Technology, Jiangsu Nanjing 210023,China.

aweixingsandra@gmail.com, bminut_yang@foxmail.com

\section{Chinese library classification No.: F253 Document code: A}

\begin{abstract}
This paper applies the Quality Function Deployment (QFD) Method to the analysis on after-sales service quality of the automobile 4S store. With the case of 4S store, the model of customer demand for after-sales service quality has been established based on the theory of SERVQUAL; the weight of customer demand has been obtained with AHP method, and the capability evaluations on market competitiveness and technical competitiveness have been made to determine elements for after-sales service; then, the Quality House of after-sales service of $4 \mathrm{~S}$ store has been built; finally, the key demands for after-sales service quality are put into specific departments to find critical factors affecting after-sales service and put forward some suggestions for improvement. The research in the paper is of great significance to improvement of after-sales service quality of $4 \mathrm{~S}$ store.
\end{abstract}

Key words: 4S store ,after-sales service, quality function deployment(QFD), Quality House.

\section{Introduction}

With the rapid development of the automotive industry, more and more 4S stores of automobile brand have burst into the scene of people. To stand out in the fierce market competition, the improvement of after-sales service quality of $4 \mathrm{~S}$ stores is extremely urgent. QFD analysis on after-sales service quality of $4 \mathrm{~S}$ stores will help stores themselves to well and deeply know their situation and find out improvement breakthrough, so as to enhance the after-sales service quality, promote customer satisfaction and finally increase the loyalty of customer on $4 \mathrm{~S}$ store.

\section{Concept and QFD theory of after-sales service quality of automobile}

\subsection{Concept of after-sales service quality of automobile}

As a critically important link in the field of circulation of automobile, the after-sales service is a huge project, including quality guarantee, compensation, repair, maintenance, components and parts consultation and guidance, information feedback and any other contents related to market products after the sale of an automobile. As a significant role in automobile sales, the after-sales service is a double-edged sword, which possibly facilitates and supports the marketing, reputation and brand influence and market promotion, but simultaneously may cause the reduction of product sales and brand reputation, or even worse, destroys a brand. This importance [1] has been provided in the operation of foreign automobile market for decades of years. 


\subsection{Meaning and content of QFD}

QFD (Quality Function Deployment) means converting customer's requirements into product or service quality characteristics for such guarantee in which customer's key demands and enterprise's core technologies could be systematically put into quality characteristics, such as any functional components, process variables and service factors, so as to meet the product or service quality required by the customer. QFD recognizes critical quality characteristics by defining what is to be done (customer's requirement) and "how to do" (quality characteristics), and puts quality factors defined by the customer into product or services [2].

Use the user demand as the basis, with technology deployment, reliability deployment, cost deployment or service deployment, QFD specifies problems to be solved, and relevant department is reported; then, it becomes the starting point and breakthrough of quality improvement.

\subsection{Principle and composition of the Quality House}

In 1988, J.R. Hauser and Don Clausing, American scholars, proposed the concept of Quality House which is also referred to as quality chart. The Quality House is a tool of QFD Method and a visual form of matrix frame representation. Basic form is shown as Fig. 1[3].

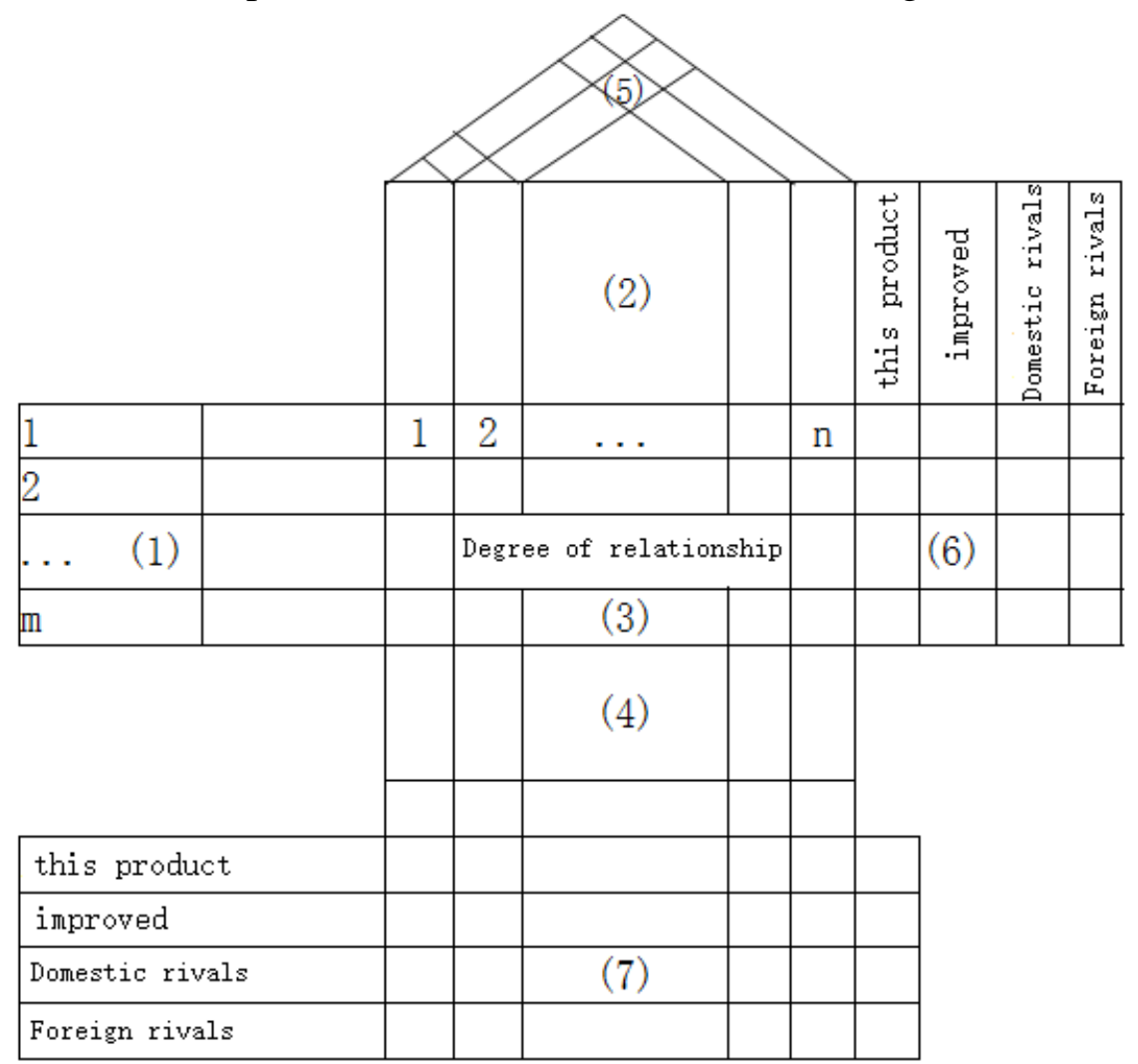

Fig. 1 Quality House

Basic structural elements are shown as follows:

(1) Left wall - customer's demand and its importance;

(2) Ceiling - requirements or characteristics for product (or service);

(3) Room - Relationship matrix;

(4) Floor - index and importance of works (or service) measures

(5) Roof - correlation matrix

(6) Right wall - Capacity evaluation matrix of market competition;

(7) Basement - Capacity evaluation matrix of technical competition 


\subsection{Analysis on customer's demands for after-sales service of the automobile 4S store}

The first step of QFD is to analyze the demands of customer (i.e.: voice of the customer, abbreviated as VOC). Analysis on customer's demands is a critical step that requires special attention. When analysis on customer's demands, the changes of external and internal environment of an organization, the abstraction and indeterminacy of customer's demand all shall be considered, and the complete information [4] with strong timeliness shall be collected as much as possible.

\subsubsection{Investigation on customer's demand content}

The investigation on customer's demand content is divided into two stages. The first stage uses the face-to-face investigation method to overall know about the content of customer's demand in 4S store, while the second stage uses questionnaire method. Based on the theory of SERVQUAL, the questionnaire is designed around the service elements to obtain the score of customer on importance of service needs. Statistical processing of the questionnaire has been made, and the customer's key demands are shown in Table 1.

Table 1 After-sales service quality of 4S store customer's key demands table

\begin{tabular}{|c|c|}
\hline & Customer’s demands \\
\hline First index & Secondary index \\
\hline \multirow{7}{*}{ reception services } & 1.Inform cost before service \\
\hline & 2.Staff communication ability \\
\hline & 3.Handle customer complaints in time \\
\hline & 4.Reception staff friendly and patient \\
\hline & 5.4S shop environment maintenance \\
\hline & 6.To provide users with a good leisure waiting place \\
\hline & 7.Take the initiative to meet and guide the customer \\
\hline \multirow{8}{*}{$\begin{array}{c}\text { maintenance } \\
\text { service }\end{array}$} & 8.Maintenance staff skilled in computer application \\
\hline & 9.Know the relevant maintenance laws and regulations \\
\hline & 10.Use the original factory accessories \\
\hline & 11.High performance/price ratio of repair parts \\
\hline & 12.Maintenance staff have car professional knowledge \\
\hline & 13.comprehensive car examination \\
\hline & 14.Customers can watch repair process \\
\hline & 15.Carefully listen to the customer's requirements and the description of car's failure \\
\hline \multirow{3}{*}{$\begin{array}{c}\text { Time } \\
\text { commitments }\end{array}$} & 16.Estimated finish time is relatively accurate \\
\hline & 17.The maintenance time is reasonable \\
\hline & 18.To make an convenient time appointment to customers \\
\hline \multirow{5}{*}{ Pay car service } & 19.inform the process and ask customers' opinion for old parts. \\
\hline & 20.A free car wash service \\
\hline & 21.Show customers the old parts \\
\hline & 22.Explain the repair advice and car using notice. \\
\hline & 23.Clarify the cost detail items to customers \\
\hline \multirow{2}{*}{ Follow-up service } & 24.Consult costumers if other service demands \\
\hline & 25.Quality tracking by telephone return visit. \\
\hline
\end{tabular}




\subsubsection{Determination of customer's demand weight}

After the acquisition of the customer's key demand content, the weight of each demand shall be determined. Determine the customer's demand weight [2] with AHP (Analytic Hierarchy Process).

(1) Determine the judgment matrix between customer's demands. Express the degree of importance of demand i (relative to demand j) for realization of "customer satisfaction" with $C_{i j}$.

Obviously, $C_{i j}=1 / C_{j i}$.

(2) When calculating the eigenvector, the formula is shown as follows:

$$
\begin{aligned}
& \omega_{i}=\sqrt[m]{\prod_{j=1}^{m} c_{i j}} \\
& \omega_{i}^{o}=\omega_{i} / \sum_{i=1}^{m} \omega_{i}
\end{aligned}
$$

(3) When calculating the maximum eigenvalue of importance matrix $C$, the formula is shown as follows:

$$
\lambda_{\max }=\frac{1}{n} \times \sum_{i=1}^{n} \frac{(A W)_{i}}{W_{i}}
$$

(4) When calculating the consistency index CI, the formula is shown as follows:

$$
C I=\frac{\lambda \max -m}{m-1}
$$

(5) When calculating the random consistency ratio CR, the formula is shown as follows:

$$
C R=\frac{C I}{R I}
$$

In the above formula, RI is the average random consistency index, and see Table 2 for the value. When CR is not greater than 0.1 , the consistency test is adopted; when CR is greater than 0.1 , the consistency test does not pass, and the judgment matrix should be redefined.

Table 2 RI value

\begin{tabular}{|c|c|c|c|c|c|c|c|}
\hline Importance ScaleMatrix order & 3 & 4 & 5 & 6 & 7 & 8 & 9 \\
\hline RI & 0.58 & 0.90 & 1.12 & 1.24 & 1.32 & 1.41 & 1.45 \\
\hline
\end{tabular}

With the way of expert scoring, determine the judgment matrix of the demand index of key customers, and with AHP method, calculate the index weight of secondary index relative to overall index in the customer's demand, and it respectively includes $\omega_{i}{ }^{\circ}=(0.013,0.007,0.017,0.013$, $0.004,0.004,0.006,0.015,0.032,0.064,0.064,0.064,0.069,0.037,0.026,0.042,0.096$, $0.110,0.030,0.014,0.030,0.059,0.032,0.052,0.103)$.

According to the above content and weight investigated of the customer's demand, determine the left wall of the Quality House.

\subsection{Capability evaluation of market competition}

According to the demand index system and weight of key customers for after-sales service of $4 \mathrm{~S}$ store, it is possible to devise the position of after-sales service quality of $4 \mathrm{~S}$ store improved in the market. Specific way is to continue to make research, visit experts and compare their own 
service with that of domestic and overseas competitors (i.e. bench marking).

Through the capability evaluation on market competition of a certain 4S store, the organization should devise improvement goals in all service elements of key customer, calculate the level increase rate, and obtain the absolute weight and relative weight of each service element of key customer, so as to complete the process of quality planning and determine the right wall of the Quality House.

Specific steps [3] for capability evaluation of market completion are shown as follows:

(1) Express the score of market competition capability with $M_{i}(\mathrm{i}=1,2, \ldots, \mathrm{m})$, and request the experts to score $M_{i}$, determine the market competitiveness of this $4 \mathrm{~S}$ store compared with domestic and overseas competitors, and objectively evaluate the degree of satisfaction of this $4 \mathrm{~S}$ store and domestic and overseas competitors with customer's demand for quantitative scoring.

(2) Plan and organize the market competition capability of service quality after improvement, and determine the score of market competitiveness after improvement.

(3) When calculating the level increase rate, absolute weight and relative weight, the formula is as follows:

Level increase rate $L_{i}=$ market competition capability after improvement / market competition capability before improvement

Absolute weight $=$ importance $\times$ level increase rate;

Relative weight $=$ (absolute weight $/$ sum of absolute weight of each demand $) \times 100 \%$.

(4) When calculating the "index of market competitiveness", the formula is as follows:

$$
M=\frac{\sum_{i=1}^{m} K_{i} M_{i}}{5 \sum_{i=1}^{m} K_{i}}
$$

In the above formula, $\mathrm{K}$ is the importance of service element, and the greater the value of $\mathrm{M}$ is, the stronger the market competitiveness becomes.

(5) Based on the above data, establish the evaluation table for market competition capability of $4 \mathrm{~S}$ store, which is shown as Table 3.

Table 3 Market competition capability of 4S store

\begin{tabular}{|c|c|c|c|c|c|c|c|c|c|}
\hline \multirow[b]{2}{*}{ Key service quality requirements } & \multirow{2}{*}{ 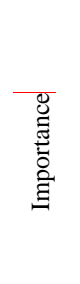 } & \multicolumn{3}{|c|}{ Comparative analysis } & \multicolumn{2}{|c|}{$\begin{array}{l}\text { Improvement } \\
\text { rate }\end{array}$} & \multicolumn{3}{|c|}{$\begin{array}{l}\text { Sequencing of key customers' } \\
\text { demands }\end{array}$} \\
\hline & & $\begin{array}{c}\text { 4S } \\
\text { store }\end{array}$ & 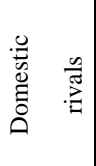 & 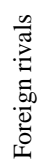 & 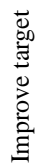 & 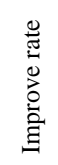 & $\begin{array}{l}\text { Service } \\
\text { features }\end{array}$ & $\begin{array}{l}\text { Absolute } \\
\text { weight }\end{array}$ & $\begin{array}{l}\text { Relative } \\
\text { weight }\end{array}$ \\
\hline 1.Inform cost before service & 0.013 & 3 & 3 & 4 & 4 & 1.3 & 1.2 & 2.0 & 1.6 \\
\hline 2.Staff communication ability & 0.007 & 4 & 4 & 5 & 5 & 1.3 & 1.2 & 1.1 & 0.8 \\
\hline $\begin{array}{l}\text { 3.Handle customer complaints in } \\
\text { time }\end{array}$ & 0.017 & 4 & 3 & 4 & 4 & 1.0 & 1.5 & 2.6 & 2.0 \\
\hline 4.Reception staff friendly and patient & 0.013 & 4 & 3 & 5 & 5 & 1.3 & 1.5 & 2.4 & 1.8 \\
\hline 5.4S shop environment maintenance & 0.004 & 4 & 4 & 5 & 5 & 1.3 & 1.0 & 0.4 & 0.3 \\
\hline $\begin{array}{l}\text { 6.To provide users with a good } \\
\text { leisure waiting place }\end{array}$ & 0.004 & 5 & 4 & 5 & 5 & 1.0 & 1.0 & 0.4 & 0.3 \\
\hline $\begin{array}{l}\text { 7.Take the initiative to meet and } \\
\text { guide the customer }\end{array}$ & 0.006 & 4 & 4 & 4 & 4 & 1.0 & 1.0 & 0.6 & 0.5 \\
\hline 8.Maintenance staff skilled in & 0.015 & 4 & 4 & 4 & 4 & 1.0 & 1.0 & 1.5 & 1.1 \\
\hline
\end{tabular}




\begin{tabular}{|c|c|c|c|c|c|c|c|c|c|}
\hline computer application & & & & & & & & & \\
\hline $\begin{array}{l}\text { 9.Know the relevant maintenance } \\
\text { laws and regulations }\end{array}$ & 0.032 & 3 & 3 & 4 & 4 & 1.3 & 1.0 & 4.3 & 3.2 \\
\hline $\begin{array}{l}\text { 10.Use the original factory } \\
\text { accessories }\end{array}$ & 0.064 & 5 & 4 & 5 & 5 & 1.0 & 1.5 & 9.6 & 7.3 \\
\hline $\begin{array}{l}\text { 11.High performance/price ratio of } \\
\text { repair parts }\end{array}$ & 0.064 & 5 & 3 & 5 & 5 & 1.0 & 1.2 & 7.7 & 5.8 \\
\hline $\begin{array}{l}\text { 12.Maintenance staff have car } \\
\text { professional knowledge }\end{array}$ & 0.064 & 4 & 3 & 5 & 4 & 1.0 & 1.0 & 6.4 & 4.9 \\
\hline 13.comprehensive car examination & 0.069 & 4 & 4 & 5 & 5 & 1.3 & 1.0 & 8.7 & 6.6 \\
\hline $\begin{array}{l}\text { 14.Customers can watch repair } \\
\text { process }\end{array}$ & 0.037 & 5 & 4 & 5 & 5 & 1.0 & 1.0 & 3.7 & 2.8 \\
\hline $\begin{array}{l}\text { 15.Carefully listen to the customer's } \\
\text { requirements and the description of } \\
\text { car's failure }\end{array}$ & 0.026 & 3 & 3 & 4 & 4 & 1.3 & 1.0 & 3.5 & 2.7 \\
\hline $\begin{array}{l}\text { 16.Estimated finish time is relatively } \\
\text { accurate }\end{array}$ & 0.042 & 4 & 3 & 4 & 5 & 1.3 & 1.2 & 6.3 & 4.8 \\
\hline $\begin{array}{l}\text { 17.The maintenance time is } \\
\text { reasonable }\end{array}$ & 0.096 & 4 & 3 & 5 & 5 & 1.3 & 1.2 & 14.4 & 11.0 \\
\hline $\begin{array}{l}\text { 18.To make an convenient time } \\
\text { appointment to customers }\end{array}$ & 0.110 & 5 & 4 & 5 & 5 & 1.0 & 1.2 & 13.2 & 10.0 \\
\hline $\begin{array}{l}\text { 19.inform the process and ask } \\
\text { customers' opinion for old parts. }\end{array}$ & 0.030 & 4 & 4 & 5 & 5 & 1.3 & 1.0 & 3.7 & 2.8 \\
\hline 20.A free car wash service & 0.014 & 5 & 5 & 5 & 5 & 1.0 & 1.2 & 1.6 & 1.2 \\
\hline 21.Show customers the old parts & 0.030 & 3 & 3 & 5 & 4 & 1.3 & 1.0 & 3.9 & 3.0 \\
\hline $\begin{array}{l}\text { 22.Explain the repair advice and car } \\
\text { using notice. }\end{array}$ & 0.059 & 3 & 3 & 4 & 4 & 1.3 & 1.0 & 7.9 & 6.0 \\
\hline $\begin{array}{l}\text { 23.Clarify the cost detail items to } \\
\text { customers }\end{array}$ & 0.032 & 3 & 3 & 5 & 4 & 1.3 & 1.5 & 6.4 & 4.9 \\
\hline $\begin{array}{l}\text { 24.Consult costumers if other service } \\
\text { demands }\end{array}$ & 0.052 & 4 & 4 & 5 & 5 & 1.3 & 1.0 & 6.4 & 4.9 \\
\hline $\begin{array}{l}\text { 25.Quality tracking by telephone } \\
\text { return visit. }\end{array}$ & 0.103 & 4 & 4 & 5 & 5 & 1.3 & 1.0 & 12.9 & 9.8 \\
\hline Market competition ability index & & 0.820 & 0.705 & 0.958 & 0.941 & & Total & 131.5 & 100.0 \\
\hline
\end{tabular}

\subsection{Determination of after-sales service elements}

Relation matrix of service element and key service quality demand shall be expressed by $r_{i j}$, given that computational formula[3] of "service element importance" of "relative weight of customer demand" is as follows:

$$
h_{j}=\sum_{i=1}^{m} k_{i} r_{i j}
$$

In above formula, assumed that a "service element" is closely concerned with most "customer service quality demands", and these customer demands are relatively important (i.e. value of $K_{i}$ being relatively great), value of $h_{j}$ increases with it, i.e.: the service element being more important.

Synthesizing above elements, it is determined that service element importance of $4 \mathrm{~S}$ store is as shown in table 4, and ceiling of the Quality House can be determined. 
Table 4 Relationship matrix of service element and key service quality demand

\begin{tabular}{|c|c|c|c|c|c|c|c|c|c|c|c|c|c|c|c|c|}
\hline \multirow[b]{2}{*}{ Key service quality demand } & \multirow[b]{2}{*}{$\begin{array}{l}\text { Relative } \\
\text { weight }\end{array}$} & \multicolumn{15}{|c|}{ Service elements } \\
\hline & & 营 & 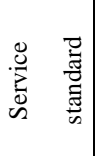 & 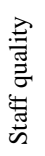 & 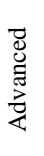 & 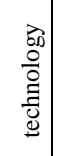 & 胥 & 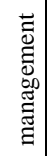 & : & 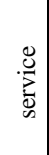 & نे & 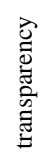 & 䔍 & 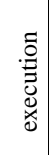 & 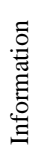 & 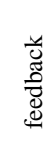 \\
\hline 1.Inform cost before service & 1.6 & 1 & 7 & 5 & 3 & 3 & 7 & & 2 & 2 & 9 & & 6 & & & 3 \\
\hline 2.Staff communication ability & 0.8 & 1 & 3 & 9 & 2 & 2 & 8 & & 3 & 3 & 1 & & 6 & 5 & & 5 \\
\hline 3.Handle customer complaints in time & 2 & 1 & 9 & 7 & 5 & 5 & 7 & & 3 & 3 & 2 & & 8 & 3 & & 5 \\
\hline 4.Reception staff friendly and patient & 1.8 & 1 & 5 & 9 & 2 & 2 & 7 & & 5 & 5 & 2 & . & 7 & 7 & & 2 \\
\hline 5.4S shop environment maintenance & 0.3 & 5 & 1 & 6 & 2 & 2 & 9 & & 2 & 2 & 2 & the & 8 & 3 & & 1 \\
\hline $\begin{array}{l}6 . \text { To provide users with a good leisure } \\
\text { waiting place }\end{array}$ & 0.3 & 9 & 5 & 5 & 2 & 2 & 7 & & 7 & 7 & 2 & & 7 & 7 & & 2 \\
\hline $\begin{array}{l}\text { 7.Take the initiative to meet and guide } \\
\text { the customer }\end{array}$ & 0.5 & 1 & 7 & 6 & 2 & 2 & 5 & & 7 & 7 & 2 & . & 7 & 7 & & 2 \\
\hline $\begin{array}{l}\text { 8.Maintenance staff skilled in } \\
\text { computer application }\end{array}$ & 1.1 & 2 & 3 & 8 & $\epsilon$ & 6 & 5 & & 2 & 2 & 2 & & 2 & 2 & & 1 \\
\hline $\begin{array}{l}\text { 9.Know the relevant maintenance } \\
\text { laws and regulations }\end{array}$ & 3.2 & 1 & 3 & 7 & 3 & 3 & 3 & & 3 & 3 & 2 & ? & 3 & 3 & & 2 \\
\hline $\begin{array}{l}\text { 10.Use the original factory } \\
\text { accessories }\end{array}$ & 7.3 & 2 & 8 & 6 & & 3 & 7 & & 2 & 2 & 5 & ; & 7 & 7 & & 3 \\
\hline $\begin{array}{l}\text { 11.High performance/price ratio of } \\
\text { repair parts }\end{array}$ & 5.8 & 3 & 2 & 3 & $\epsilon$ & 6 & 2 & & 3 & 3 & 2 & & 3 & 3 & & 2 \\
\hline $\begin{array}{l}\text { 12.Maintenance staff have car } \\
\text { professional knowledge }\end{array}$ & 4.9 & 2 & 3 & 9 & 6 & 6 & 6 & & 3 & 3 & 2 & ? & 6 & 5 & & 2 \\
\hline 13.comprehensive car examination & 6.6 & 2 & 3 & 6 & 6 & 6 & 7 & & 2 & 2 & 3 & 3 & 7 & 7 & & 2 \\
\hline $\begin{array}{l}\text { 14.Customers can watch repair } \\
\text { process }\end{array}$ & 2.8 & 5 & 7 & 2 & 5 & 5 & 3 & & 5 & 5 & 3 & 3 & 5 & 5 & & 2 \\
\hline $\begin{array}{l}\text { 15.Carefully listen to the customer's } \\
\text { requirements and the description of } \\
\text { car's failure }\end{array}$ & 2.7 & 2 & 5 & 7 & 3 & 3 & 5 & & 2 & 2 & 3 & 3 & 5 & 5 & & 7 \\
\hline $\begin{array}{l}\text { 16.Estimated finish time is relatively } \\
\text { accurate }\end{array}$ & 4.8 & 5 & 5 & 5 & 7 & 7 & 6 & & 3 & 3 & 2 & ? & 6 & 5 & & 2 \\
\hline $\begin{array}{l}\text { 17.The maintenance time is } \\
\text { reasonable }\end{array}$ & 11 & 2 & 5 & 5 & & 6 & 7 & & 2 & 2 & 3 & 3 & 7 & 7 & & 2 \\
\hline $\begin{array}{l}\text { 18.To make an convenient time } \\
\text { appointment to customers }\end{array}$ & 10 & 2 & 6 & 3 & 2 & 2 & 3 & & 2 & 2 & 3 & 3 & 2 & 2 & & 2 \\
\hline $\begin{array}{l}\text { 19.inform the process and ask } \\
\text { customers' opinion for old parts. }\end{array}$ & 2.8 & 2 & 5 & 6 & 2 & 2 & 6 & & 3 & 3 & 7 & 7 & 2 & 2 & & 2 \\
\hline 20.A free car wash service & 1.2 & 5 & 5 & 2 & 5 & 5 & 2 & & 9 & ) & 3 & 3 & 2 & 2 & & 2 \\
\hline 21.Show customers the old parts & 3 & 2 & 5 & 6 & 5 & 5 & 7 & & 2 & 2 & 7 & 7 & 7 & 7 & & 2 \\
\hline $\begin{array}{l}\text { 22.Explain the repair advice and car } \\
\text { using notice. }\end{array}$ & 6 & 2 & 5 & 6 & & 2 & 2 & & 3 & 3 & 2 & 2 & 3 & 3 & & 9 \\
\hline $\begin{array}{l}\text { 23.Clarify the cost detail items to } \\
\text { customers }\end{array}$ & 4.9 & 2 & 5 & 6 & & 2 & 5 & & 3 & 3 & 9 & $\Rightarrow$ & 5 & 5 & & 2 \\
\hline 24.Consult costumers if other service & 4.9 & 1 & 5 & 6 & 3 & 3 & 2 & & 2 & 2 & 2 & 2 & 3 & & & 2 \\
\hline
\end{tabular}




\begin{tabular}{|l|c|c|c|c|c|c|c|c|c|c|}
\hline demands & & & & & & & & & & \\
\hline $\begin{array}{l}\text { 25.Quality tracking by telephone } \\
\text { return visit. }\end{array}$ & 9.8 & 1 & 5 & 2 & 2 & 5 & 2 & 2 & 5 & 9 \\
\hline \multicolumn{2}{|l|}{ Importance of service element। } & 211 & 498 & 513 & 388 & 498 & 261 & 330 & 495 & 340 \\
\hline \multicolumn{2}{|c|}{ Relative weight of service element } & 6 & 14 & 15 & 11 & 14 & 7 & 9 & 14 & 10 \\
\hline
\end{tabular}

\subsection{Technical competitive capacity evaluation}

"Technical competitive capacity level" is expressed in T while $T_{i}$ represents "technical level of the $i^{\text {th }}$ project measure". "Technical competitive capacity index" represents computational results gained after technical competitive capacity $T_{i}(1,2, \ldots, \mathrm{m})$ is synthesized and computational formula[3] is as follows:

$$
T=\frac{\sum_{j=1}^{m} h_{j} M_{j}}{5 \sum_{j=1}^{m} h_{j}}
$$

In above formula, the greater the value of $T$ is, the stronger the technical competitive capacity will be.

Synthesizing above elements, technical competitive capacity evaluation table of $4 \mathrm{~S}$ store is as shown in table 5 and basement of the Quality House can be determined.

Table 5 Technical competitive capacity evaluation table of 4S store

\begin{tabular}{|c|c|c|c|c|c|c|c|c|c|c|c|c|c|}
\hline \multicolumn{2}{|c|}{ Service elements } & 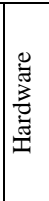 & : & 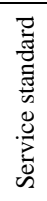 & 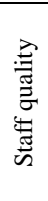 & 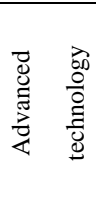 & 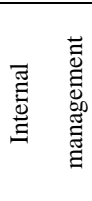 & 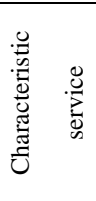 & 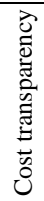 & 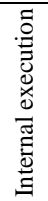 & 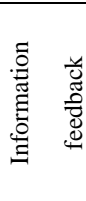 & & \\
\hline \multicolumn{2}{|c|}{$\begin{array}{c}\text { Relative weight of service } \\
\text { elements }\end{array}$} & $\epsilon$ & 6 & 14 & 15 & 11 & 14 & 7 & 9 & 14 & 10 & & \\
\hline \multirow{2}{*}{$\begin{array}{c}\text { Technical } \\
\text { competitive }\end{array}$} & before & 4 & 4 & 4 & 3 & 3 & 3 & 3 & 4 & 3 & 3 & 0.685 & \multirow{4}{*}{$\begin{array}{c}\text { Technical } \\
\text { competitiv } \\
\text { e capacity } \\
\text { index }\end{array}$} \\
\hline & after & 5 & 5 & 5 & 4 & 4 & 4 & 4 & 5 & 4 & 4 & 0.885 & \\
\hline \multirow[t]{2}{*}{ capacity } & domestic & 3 & 3 & 4 & 3 & 3 & 3 & 3 & 3 & 2 & 2 & 0.610 & \\
\hline & foreign & 5 & 5 & 5 & 5 & 5 & 4 & 4 & 5 & 5 & 5 & 0.955 & \\
\hline
\end{tabular}

\subsection{Construction of the Quality House}

Based on above analysis results, construction of the Quality House for after-sales service of 4S store is as shown in Fig. 2. 


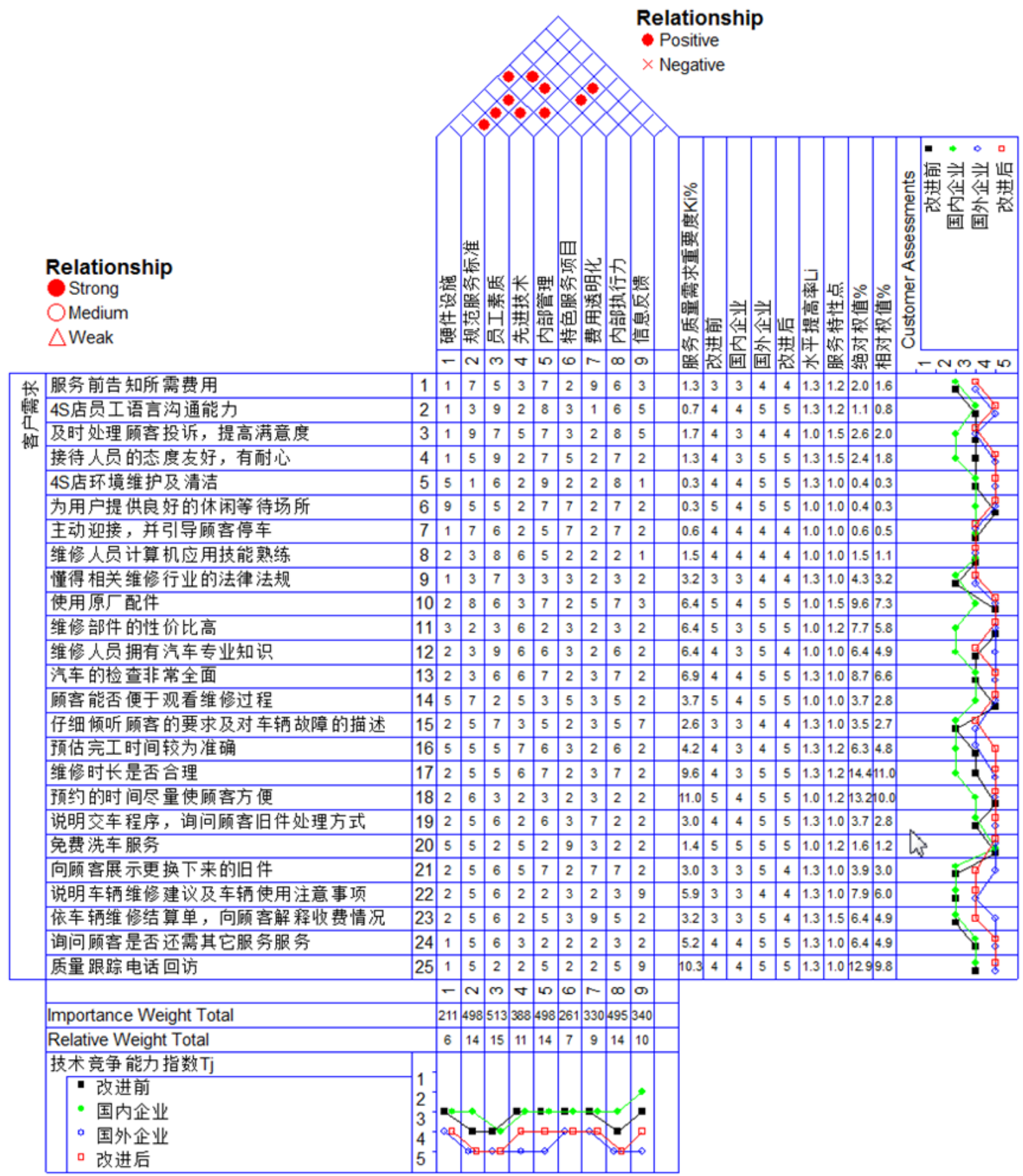

Fig.2 Quality house of 4S store after-sales service

\subsection{Determination of key after-sales service department}

"Key service quality demand" shall be implemented into each functional department of $4 \mathrm{~S}$ store to implement customer demand. 4S store mainly has 4 service departments, i.e. "service department”, “fitting department”, “technology department” and "workshop department”. Relation matrix of "key service quality demand" and "each functional department" is as shown in table 6 . Seen from computational result in table 6, service department of 4S store is the most important one, which verifies that effect of the department on customer satisfaction improvement is the most important, and the enterprise shall attach special importance to the department, and inclines to the department on human resource and material resource. At the same time, "technology department" is a relatively key functional department. 
Table 6 Relationship matrix of key service quality demand and functional department

\begin{tabular}{|c|c|c|c|c|c|}
\hline \multirow[b]{2}{*}{ Key service quality demand } & \multirow{2}{*}{$\begin{array}{l}\text { Relative } \\
\text { weight }\end{array}$} & \multicolumn{4}{|c|}{ 4S store organization structure } \\
\hline & & $\begin{array}{c}\text { Service } \\
\text { department }\end{array}$ & $\begin{array}{l}\text { Spare part } \\
\text { department }\end{array}$ & $\begin{array}{l}\text { Technical } \\
\text { department }\end{array}$ & $\begin{array}{l}\text { Workshop } \\
\text { department }\end{array}$ \\
\hline 1.Inform cost before service & 1.6 & 7 & 5 & 1 & 6 \\
\hline 2.Staff communication ability & 0.8 & 9 & 6 & 6 & 6 \\
\hline 3.Handle customer complaints in time & 2 & 9 & 7 & 5 & 8 \\
\hline 4.Reception staff friendly and patient & 1.8 & 9 & 5 & 2 & 5 \\
\hline 5.4S shop environment maintenance & 0.3 & 6 & 2 & 2 & 3 \\
\hline 6.To provide users with a good leisure waiting place & 0.3 & 5 & 1 & 1 & 1 \\
\hline 7.Take the initiative to meet and guide the customer & 0.5 & 7 & 1 & 1 & 1 \\
\hline 8.Maintenance staff skilled in computer application & 1.1 & 8 & 5 & 6 & 4 \\
\hline 9.Know the relevant maintenance laws and regulations & 3.2 & 7 & 3 & 3 & 3 \\
\hline 10.Use the original factory accessories & 7.3 & 5 & 9 & 3 & 7 \\
\hline 11.High performance/price ratio of repair parts & 5.8 & 3 & 7 & 6 & 3 \\
\hline 12.Maintenance staff have car professional knowledge & 4.9 & 5 & 6 & 8 & 8 \\
\hline 13.comprehensive car examination & 6.6 & 5 & 3 & 9 & 5 \\
\hline 14.Customers can watch repair process & 2.8 & 7 & 5 & 5 & 8 \\
\hline $\begin{array}{l}\text { 15.Carefully listen to the customer's requirements and } \\
\text { the description of car's failure }\end{array}$ & 2.7 & 7 & 5 & 7 & 5 \\
\hline 16.Estimated finish time is relatively accurate & 4.8 & 5 & 6 & 7 & 6 \\
\hline 17.The maintenance time is reasonable & 11 & 5 & 7 & 6 & 7 \\
\hline $\begin{array}{l}\text { 18.To make an convenient time appointment to } \\
\text { customers }\end{array}$ & 10 & 6 & 3 & 8 & 2 \\
\hline $\begin{array}{l}\text { 19.inform the process and ask customers' opinion for old } \\
\text { parts. }\end{array}$ & 2.8 & 6 & 6 & 2 & 2 \\
\hline 20.A free car wash service & 1.2 & 5 & 2 & 2 & 7 \\
\hline 21.Show customers the old parts & 3 & 6 & 7 & 5 & 7 \\
\hline 22.Explain the repair advice and car using notice. & 6 & 6 & 2 & 2 & 3 \\
\hline 23.Clarify the cost detail items to customers & 4.9 & 6 & 5 & 5 & 5 \\
\hline 24.Consult costumers if other service demands & 4.9 & 6 & 2 & 3 & 3 \\
\hline 25.Quality tracking by telephone return visit. & 9.8 & 7 & 2 & 8 & 2 \\
\hline \multicolumn{2}{|l|}{ 4S store department importance } & 584 & 477 & 558 & 469 \\
\hline \multicolumn{2}{|l|}{ Relative weight of department } & 28.0 & 22.9 & 26.7 & 22.5 \\
\hline
\end{tabular}

\section{Suggestion on improvement of after-sales service quality of automobile 4S store}

Aimed at QFD analysis of an automobile 4S store, suggestion on improvement of after-sales service quality is as follows:

\subsection{Improve overall quality of the staff}

Automobile after-sales service has service nature, business nature and technology nature simultaneously and therefore, overall quality here contains professional skill quality for automobile maintenance and comprehensive quality of personnel. It is suggested that the staff should be properly reeducated, trained and assessed regularly according to requirements of ISO9001 quality management system to guarantee that all personnel devoted to work concerned with service quality possess professional automobile maintenance and detection technology and relatively strong 
after-sales service ability.

Only improvement of business ability and comprehensive quality of the staff can guarantee that satisfying after-sales service can be provided for customer, including comprehensive service, such as warm and thoughtful reception service, comprehensive and correct failure diagnosis and elimination service, automobile maintenance and original accessory supply etc. to guarantee effectiveness and effective rate of service and improve customer satisfaction truly.

\subsection{Normalize service standard and strengthen information construction of $4 \mathrm{~S}$ store}

Firstly, service standard shall be normalized and strict after-sales service process and service standard specification shall be formulated. Introduce advanced management information system of 4S store. Store technology standard and service standard into database server and invoke various standards conveniently and fast through operation to information system for the convenience of execution.

Secondly, it is suggested that automobile failure diagnosis and elimination module should be increased in management information system of $4 \mathrm{~S}$ store and failure mode analysis data should be stored into database server so that sequencing of failure diagnosis and elimination work can be realized, thus reducing burden of technician and improving efficiency and correctness of failure diagnosis.

Thirdly, it is suggested that customer relation management system module should be increased in management information system of $4 \mathrm{~S}$ store and customer information should be stored into database server so that contact with customer can be more convenient and humanistic care to customer can be performed in real time, thus improving customer satisfaction and increasing dependence of customer to $4 \mathrm{~S}$ store.

\subsection{Strengthen internal management and improve internal executive force}

Optimize internal management process further and strengthen construction of internal executive force. Improvement of after-sales service quality of automobile 4S store is concerned with normative and scientific organization and management in the internal of enterprise. Therefore, organization shall establish complete management mechanism and operation mode according to its own condition and implements quality responsibility system simultaneously and implements after-sales service quality objective into each department and each employee to strengthen internal executive force of enterprise truly. In addition, scientific performance appraisal system shall be introduced to arouse the enthusiasm of staff in $4 \mathrm{~S}$ store, thus improving overall level[5] of after-sales service of a $4 \mathrm{~S}$ store.

\subsection{Introduce advanced maintenance technology and improve integrated service level}

It is suggested that a $4 \mathrm{~S}$ store should introduce advanced and modern maintenance technology and should use international leading maintenance machine, equipment and measurement diagnosis equipment etc. Only advanced maintenance equipment and excellent technology can improve correctness of automobile failure detection and maintenance efficiency, reduces maintenance and lowers maintenance cost, thus making maintenance work made under controllable conditions and guaranteeing maintenance quality and continuous improvement.

\subsection{Attach importance to collection of feedback information from customer}

It is suggested that customer satisfaction should be monitored regularly according to requirements of ISO9001 standard on "measurement, analysis and improvement", improved customer satisfaction measurement channel should be established and feedback information from customer should be collected actively and forwardly. Statistic analysis shall be performed to customer satisfaction or dissatisfaction information gained to provide basis for subsequent quality improvement, thus realizing continuous quality improvement and improving after-sales service 
quality continuously[6].

\section{Conclusion}

With increasingly fierce automobile market competition, 4S store attaches more and more importance to after-sales service quality. This paper introduces Quality Function Deployment method into after-sales service quality analysis of automobile $4 \mathrm{~S}$ store. Take a $4 \mathrm{~S}$ store as example, customer demand on after-sales service is analyzed firstly, and customer demand weight is determined through AHP method. Market competition capacity and technical competitive capacity are evaluated, after-sales service elements are determined and the Quality House of after-sales service of $4 \mathrm{~S}$ store is constructed. Finally, "key service quality demand” is implemented into each functional department of $4 \mathrm{~S}$ store and pertinent suggestion on quality improvement of $4 \mathrm{~S}$ store is proposed.

\section{Acknowledgments}

This work was financially supported by General Project for Natural Science Research of Colleges and Universities in Jiangsu (14KJB460018) fund.

\section{References}

[1] Song Lili, Zhang Xuan. Quality Evaluation Model of Service Product Based on QFD [J]. Statistics and Decision, 2009 (8): 155-156.

[2] Han Keqi. Quality Management [M]. Beijing: Chemical Industry Press, 2008.

[3] Luo Guoxun. Quality Engineering and Management [M]. Beijing: Higher Education Press, 2009.

[4] Yu Jifei, Weng Haiming. Discussion on After-sales Service Satisfaction of Automobile 4S Store [J]. Chinese E-commerce, 2013 (15): 273.

[5] Li Fan. Analysis on Existing Problem and Countermeasure of After-sales Service of Automobile [J]. Science \& Technology Information, 2009 (26): 251-252.

[6] Zhu Xueyan. How to Improve After-sales Service Level of Automobile [J]. China Logistics \& Purchasing, 2011 (5): 50-51. 